\title{
Heat treated stone artifacts at Shuidonggou, Northwest China and their archaeological implications
}

\author{
Zhenyu Zhou $^{\text {a, c, *, Yong Huan }}{ }^{\text {b, **, Yaqi Shao }}{ }^{\text {b }}$, Yujing Dai ${ }^{b}$, Haisheng Yang ${ }^{b}$ \\ ${ }^{a}$ Key Laboratory of Vertebrate Evolution and Human Origins of Chinese Academy of Sciences, Institute of Vertebrate Paleontology and Paleoanthropology, \\ Chinese Academy of Sciences, Beijing 100044, China \\ b State Key Laboratory of Nonlinear Mechanics, Institute of Mechanics, Chinese Academy of Sciences, Beijing 100190, China \\ ${ }^{\mathrm{c}}$ Institute of Archaeology, Chinese Academy of Social Sciences, Beijing 100710, China
}

\section{A R T I C L E I N F O}

\section{Article history:}

Available online 29 August 2014

\section{Keywords}

Upper Paleolithic

Modern behavior

China

Heat treatment

Mechanical properties

\begin{abstract}
A B S T R A C T
Artifacts from the Shuidonggou (SDG) site complex in Ningxia province provide extensive information and insights regarding the activities of early modern humans in China. Based on a series of experiments and physical analyses, it appears that the stone artifacts from SDG Locality 2 and Locality 12 have undergone heat treatment that enhanced the utilization ratio and knapping properties of the lithic raw material from which they were made. In order to investigate the mechanisms involved, compression tests and XRD (X-ray Diffraction) examinations were conducted on lithic raw materials collected surround the SDG sites. The results indicate that the heated stones present lower compression strength and better ductility, and the raw material becomes more homogeneous as well. The process of crack propagation also becomes easier to control, thereby reducing knapping difficulties. The application of heat treatment technology at SDG reflects the production capacities and risk management strategies of the SDG inhabitants and provides evidence for the level of understanding associated with early modern human behavior. This discovery confirms the appearance of this technology in the East Asia around $32 \mathrm{ka}$ BP (which lasts to $11 \mathrm{ka} \mathrm{BP}$ ), providing new evidence for the spread and distribution of heat treatment technology.
\end{abstract}

() 2014 Elsevier Ltd and INQUA. All rights reserved.

\section{Introduction}

The oldest anthropogenic lithic heat treatment activity is currently documented at Pinnacle Point in South Africa (164-72 ka) (Brown et al., 2009). Heat treated artifacts are also found at the Porc Epic Middle Stone Age site in Ethiopia (70 ka) (Clark and Harris, 1985). In Europe, heat treatment behavior for enhancing flake retouching is identified in Mousterian assemblages in France and Spain dated to ca. 110 ka to 63 ka (Clemente, 1995; Guibert et al., 2004; Duttine, 2005; Domanski and Webb, 2007), and also in later Upper Paleolithic and Epipaleolithic industries. For example, heat treated flint was used to make bifacial points at Kostenki 1, Ukraine, dated to 27-30 ka (Bradley et al., 1995), and in the Solutrean assemblages of France, Spain, Portugal, Poland, and Germany,

\footnotetext{
* Corresponding author. Institute of Archaeology, Chinese Academy of Social Sciences, Beijing 100710, China.

** Corresponding author.

E-mail addresses: zzy529@msn.com (Z. Zhou), huany@Inm.imech.ac.cn (Y. Huan).
}

this technology was used for improving the efficiency of pressure flaking, and the production of points, bifacial artifacts, and microblades (Owen, 1988; Aubry et al., 2003; Domanski and Webb, 2007; Domański et al., 2009). In Southwest Asia, the earliest evidence of this technology for enhancing flake retouching is from Mousterian assemblages in Lebanon (110 ka) (Copeland, 1998; Sanlaville, 1998), and in the same area, heat treated chert artifacts from Aurignacian levels at Ksar Akil site indicate intentional heating in the production of bifacial points, dated to $32 \mathrm{ka} \mathrm{BP}$ (Griffiths et al., 1987), and in the Jordan Valley, heat treated chert was used in the production of bladelets and microlithic tools at early Natufian sites (Edwards and Edwards, 1990). Heat treated technology was also used in the production of bladelets and microblades in India, Pakistan, and Afghanistan (20 ka BP-10 ka BP) (Clark and Williams, 1986). At the same time, a large number of archaeological heat treatment records have been reported in North America, and these researches reveal the well developed heat treatment skill and its application in the production of blades and bifacial artifacts (Struever, 1973; Greber et al., 1981; Morrow, 1987; Jeske, 1989; Inizan et al., 1992; Domanski and Webb, 2007). The same happened in Australia, where sites with heat treated artifacts are dated from 20 ka BP to 
the contact period (Domanski and Webb, 2007). In east Siberia, debris from Dyuktai assemblages at Ust'Mil' and Kukhtui (20 ka BP-10 ka BP) indicate intentional heat treating in the production of bifacial artifacts (Yi and Clarke, 1985; Chen and Wang, 1989; Dolukhanov and Shukurov, 2004). Based on research to date, lithic heat treatment technology is widely dispersed throughout the world, including Africa, Europe, America, Oceania, and West, Central and South Asia (Clark and Williams, 1986; Domanski and Webb, 2007; Domański et al., 2009) and was commonly used in flake knapping and retouching, especially for the production of blades, microblades, and bifacial artifacts.

Recently, Zhou et al. (2013) reported a series of simulation experiments about heat treatment research. Based on visual and microscopic observation, intra-site spatial analysis (Guan et al., 2011) intentionally heat treated artifacts have been identified at the SDG sites, Ning Xia Autonomous Region, China. These finds provide the earliest evidence of Paleolithic heat treatment in East Asia. However, it still is not clear exactly how heat treatment improves the mechanical properties of stone raw material, how heat treatment influenced the behavioral strategy of SDG inhabitants, and how this technology spread to the SDG area. In this paper, these issues will be discussed, based on the heat treated artifacts excavated at SDG and the simulated experiments.

\section{Specimens}

The SDG sites lie along a small stream (the Biangou River) on the eastern margin of the Yinchuan basin, southwest of the Mu Us Desert (Fig. 1). Zhou et al. (2013) examined part of the Locality 2 (SDG 2) and Locality 12 (SDG 12) assemblages. Heat treated stone artifacts $(n=45)$ were recovered from SDG 2 in cultural layers (CL hereafter) 1-4, dating to 32-20 ka BP (Madsen et al., 2001; Gao et al., 2009; Gao et al., 2010; Li et al., 2013b), but are primarily from CL1 dating to about $20 \mathrm{ka}$ BP. Sixty five heat treated stone artifacts were recovered from SDG 12 dated to about 11 ka BP (Gao et al., 2008; Liu et al., 2009). The raw material at SDG 12 consists primarily of dolomite and chert (Gao et al., 2013; Li et al., 2013a). Geological data and surveys (Liao, 1989; Zheng and Li, 1991) indicate there is no known local bedrock exposure of these two rock types, but dolomite could be commonly found in pebble and cobble layers of nearby stream terraces. Dolomite is widely distributed near and around the site, while high-quality chert could not be found within a $5 \mathrm{~km}$ radius from the site. Experimental specimens were collected from pebble layers near SDG 1, SDG 2, and SDG 12 (Fig. 2). All the identified heat treated artifacts are made of dolomite, chert, and chalcedony (Zhou et al., 2013), but we could not find chert blocks in sufficient volume for simulation experiment. Therefore, all the experiments and research in this paper were conducted with dolomite.

\section{Methods and tests}

Heat treatment of stone artifacts have been found at various SDG sites (Zhou et al., 2013), but it was unclear whether heat treatment actually improves the mechanical properties of stone raw material. For this study, we examined locally collected pebbles by means of simulated heating tests, material analysis, and compression tests. The advent and propagation of heat treatment behavior likely involved the alteration of stone artifact mechanical properties by changing and improving the internal crystalline structure of raw material, but research of rock engineering properties has shown that the mechanical properties of most rocks changes most markedly when it is heated to above $600{ }^{\circ} \mathrm{C}$ or, in some cases, to as high as $800^{\circ} \mathrm{C}$ (Heuze, 1983; Lau et al, 1995; Balme and Rocchi, 2004; Zhang et al., 2009). However, there are two differences between stones heated prehistorically and those heated using modern techniques: first, stones used prehistorically were usually pebbles which could be locally obtained and easily handled, but their mechanical properties varied widely because of nonhomogeneous textures; second, it was hard for Paleolithic peoples to achieve and maintain temperatures of $600{ }^{\circ} \mathrm{C}$ and higher when using an outdoor hearth.

\subsection{Simulated experiment procedures}

In this experiment, samples were heated in a GW-300C electric resistance furnace from a starting temperature of $100{ }^{\circ} \mathrm{C}$ to peak

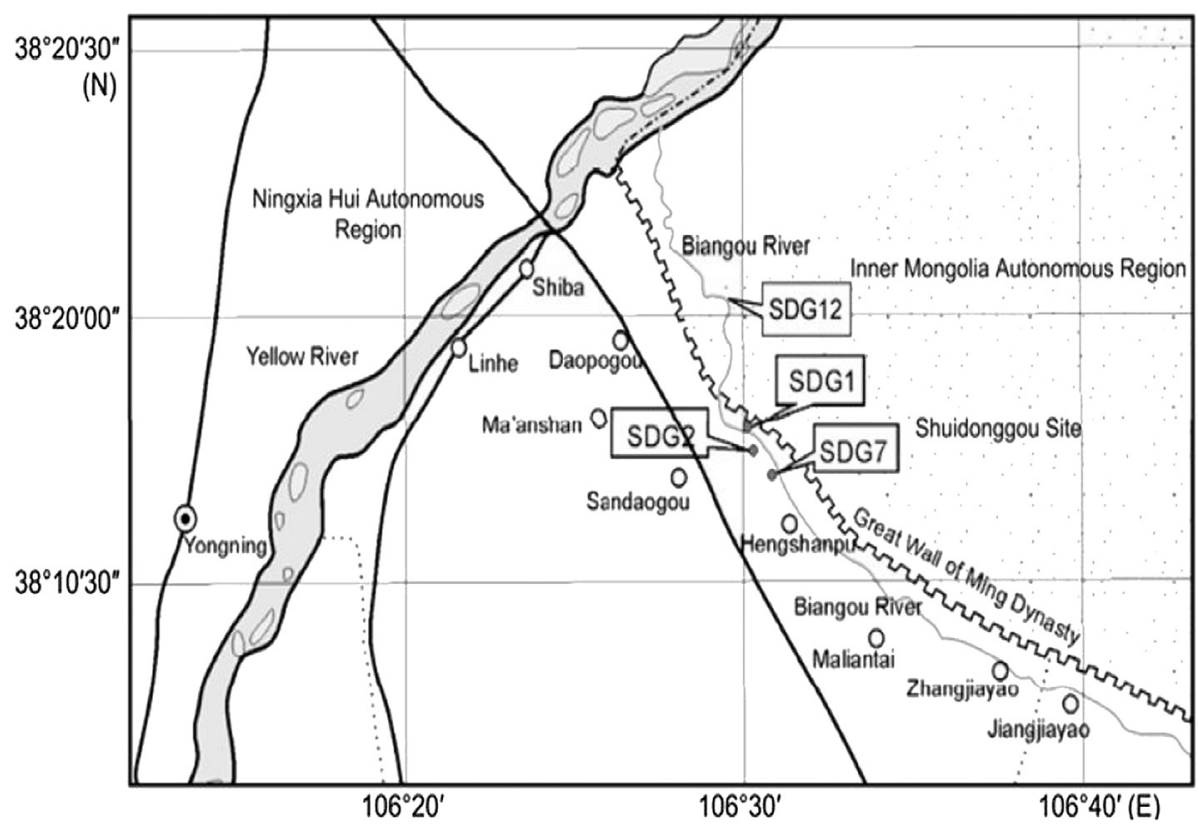

Fig. 1. Location of the Shuidonggou localities along the Biangou River. 


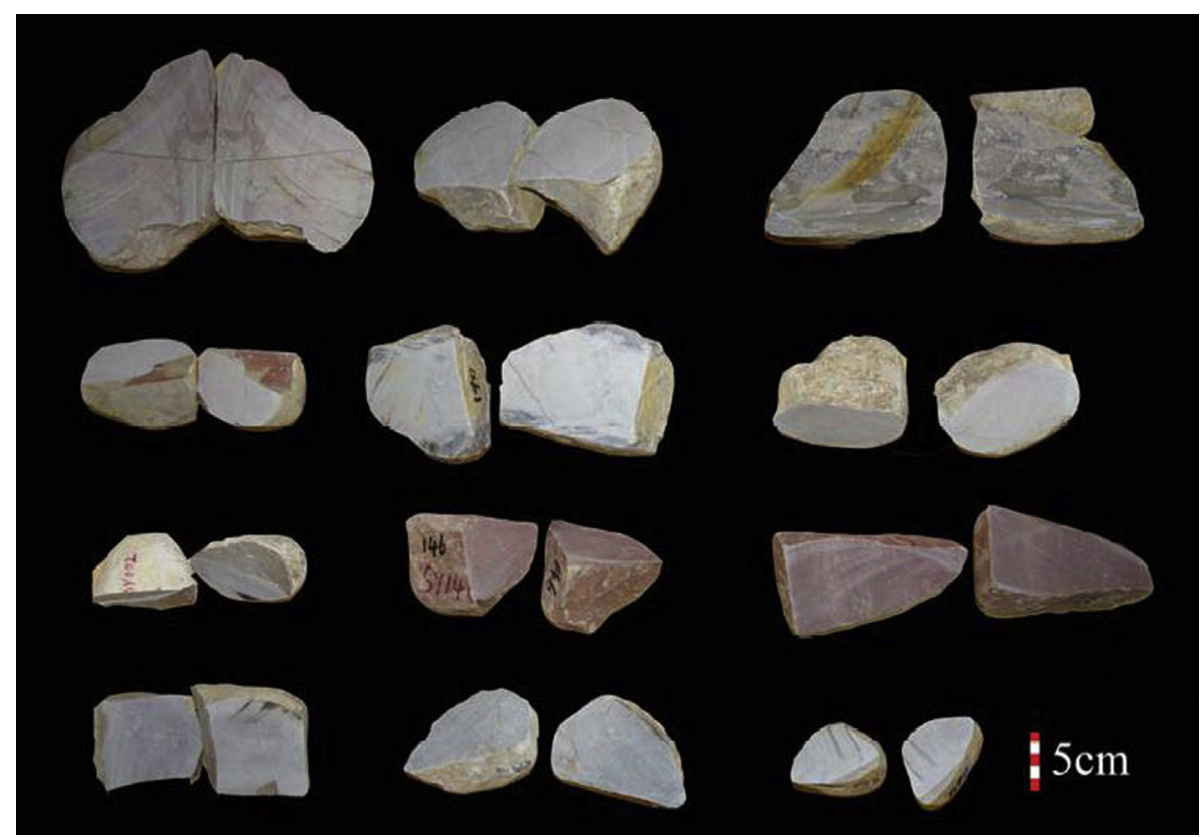

Fig. 2. Experimental pebbles collected from stream terraces near SDG localities.

temperatures of $300-550{ }^{\circ} \mathrm{C}(50 \mathrm{C}$ for a gradient $)$ at heating rates of $50 \mathrm{C} / \mathrm{h}$. Peak temperatures were maintained for $2 \mathrm{~h}$. Thereafter, the heated blanks were kept in the closed furnace and allowed to cool to air temperature over the course of approximately $14 \mathrm{~h}$. All experimental pebbles were split into pieces before heat treatment, with the separate pieces individually heated with different temperatures and cooled down at different rates.

\subsection{Compression tests}

In general, rock damage processes in compression tests include the initiation, development and nucleation of cracks (Turcotte et al., 2003) that can be reflected on strain vs. stress curves. To investigate the mechanical properties of the heated and unheated dolomite specimens, compression tests were performed using a MTS 810 material testing machine. Specimen cubes were cut out of both heat-treated and non-heat-treated pebbles for the tests. The experimental setup is shown in Fig. 3. Force is measured by the load cell, and the deformation of the specimen is measured by a COD displacement sensor fixed between two compression plates. This deformation vs. force relationship was then transformed to a strain vs. stress curve.

\section{Results}

\subsection{Strain vs. stress curves}

The strain vs. stress compression curves of the dolomite specimens are shown in Fig. 4. The results indicate that the unheated dolomite specimens have a high variance in mechanical properties, implying that they consist of a non-homogeneous material. However, the variance of mechanical properties is significantly reduced after being heated to $450{ }^{\circ} \mathrm{C}$ or $550{ }^{\circ} \mathrm{C}$, suggesting that the material become more homogeneous (Fig. 4). Furthermore, the strain vs. stress curves of the heated specimens exhibit an increasing zigzag phenomenon (Fig. $4 \mathrm{~b}$ and c),
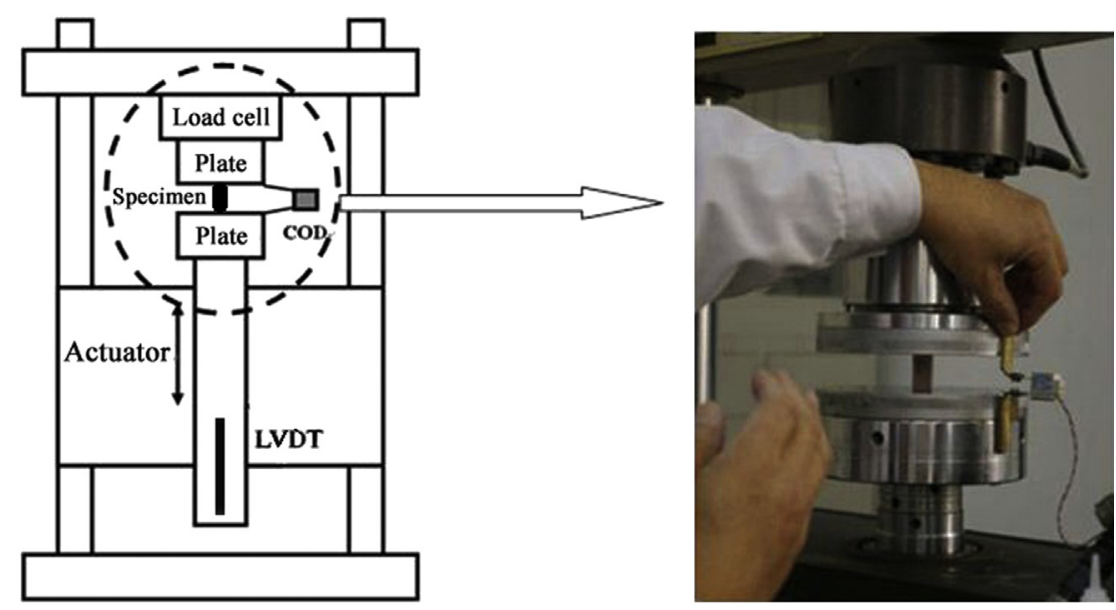

Fig. 3. Compression test setup (MTS 810 material testing machine). 


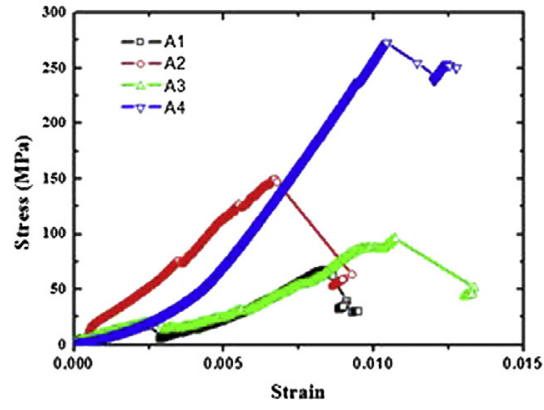

(a)

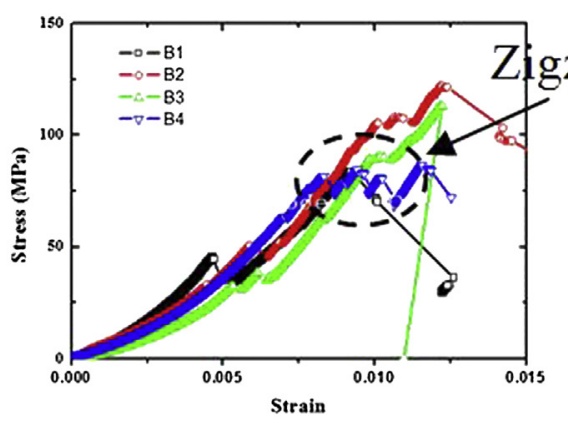

(b)

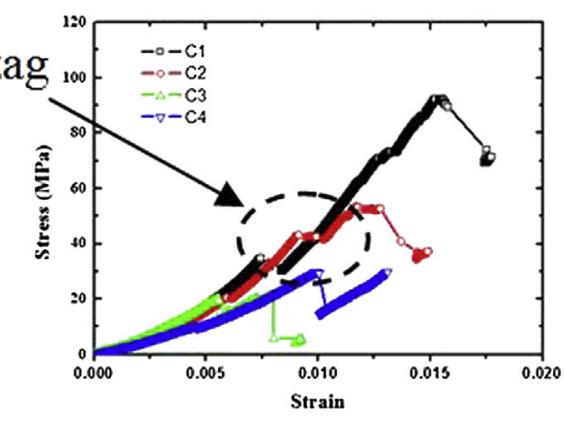

(c)

Fig. 4. Strain vs. stress curves of dolomite samples before and after heat treatment: (a) unheated samples; (b) samples heated at $450{ }^{\circ} \mathrm{C}$; (c) samples heated at $550{ }^{\circ} \mathrm{C}$.

indicating that some local cracks occur intermittently, but are not propagated due to some internal feature that prevents a catastrophic rupture. This characteristic offers opportunities for tool makers to find a proper knapping point and to adjust knapping force and directions.

\subsection{Maximum stress and maximum strain}

Because of the uneven texture of the pebbles, mechanical properties are highly variable within a single specimen. However, heat treatment could alter this characteristic. The magnitude and dispersion of the maximum compression stress are both reduced after heat treatment, as shown in Fig. 5a. The decrease of the dispersion would be advantageous to the production of stone artifacts, but too great a decrease in maximum stress may reduce the sharpness and durableness of the stone artifacts.

In the dolomite specimens we examined, at $450{ }^{\circ} \mathrm{C}$, both the dispersion of maximum stress and maximum strain is smaller, with the magnitude of the maximum stress being reduced while the magnitude of the maximum strain increased. This suggests the most appropriate temperature for knapping these specimens is likely to be about $450{ }^{\circ} \mathrm{C}$.

The maximum strain of the heated dolomite specimens is larger than that of the unheated specimens, which means better ductility to some extent. Better ductility is advantageous for finding proper knapping points, adjusting knapping force, direction, and producing longer and thinner flakes.

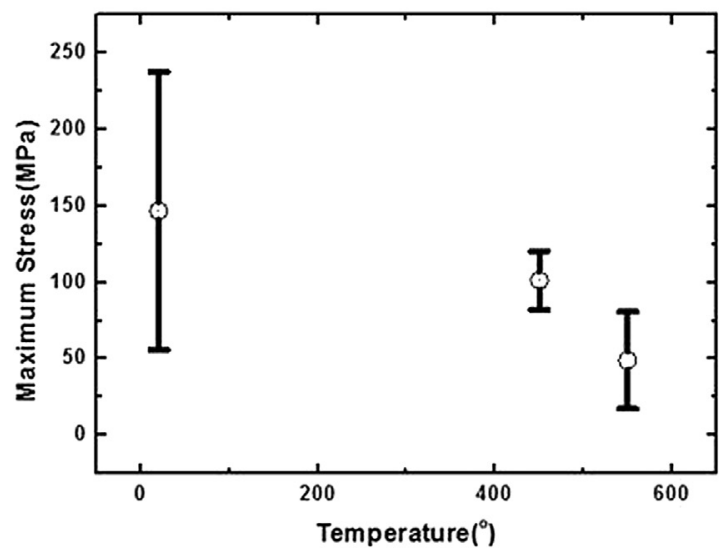

(a)

\subsection{Material analysis}

Changes in the mechanical properties of dolomite specimens are likely associated with texture. We investigated the texture of the dolomite specimens by means of X-ray diffraction (XRD). Previous research has shown that the granules of heated siliceous rock became smaller and the texture more homogeneous as a result of recrystallization (Domanski and Webb, 1992). XRD results, shown in Fig. 6, confirm this change. The diffraction intensity of $\mathrm{SiO}_{2}$ decreases after heat treatment while the diffraction intensity of $\mathrm{CaMg}\left(\mathrm{CO}_{3}\right)_{2}$ increases, in agreement with the compression test results. The decrease of $\mathrm{SiO}_{2}$ content means that the strength of the dolomite specimens decreases after heat treatment. The increase in calcium also leads to the specimens becoming brittle, as illustrated by the zigzag pattern in the strain vs. stress curves.

\section{Discussion and perspective}

\subsection{Impact of heat treatment in SDG}

Heat treated artifacts have been identified in SDG by visual recognition criteria and microscopic observations (Zhou et al., 2013). The influence of heat treatment on making stone artifacts for Paleolithic humans is studied by means of experimental mechanics. The compression test results indicate that the heated specimens have more uniform mechanical properties, with a better

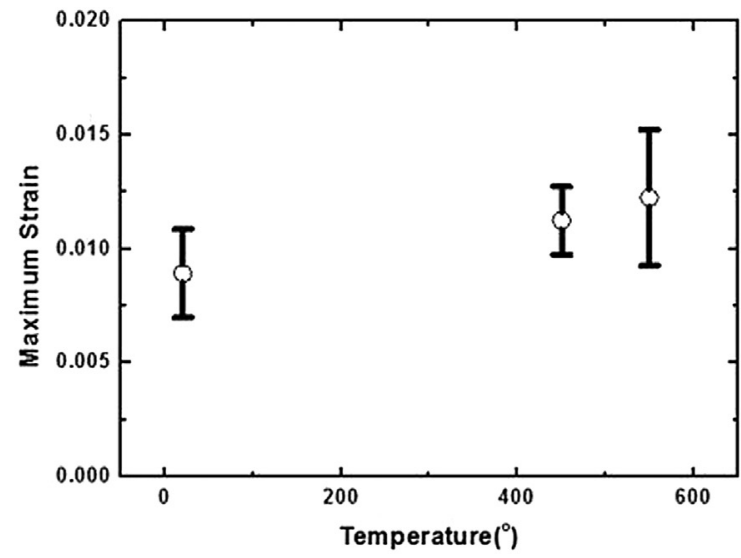

(b)

Fig. 5. (a) Maximum stress, (b) Maximum strain with different heat treatment temperatures. 


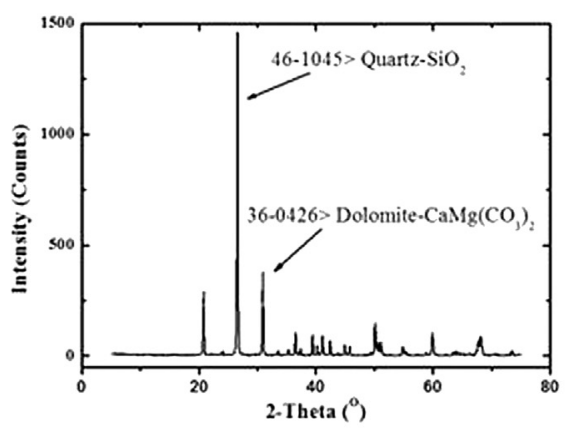

(a)

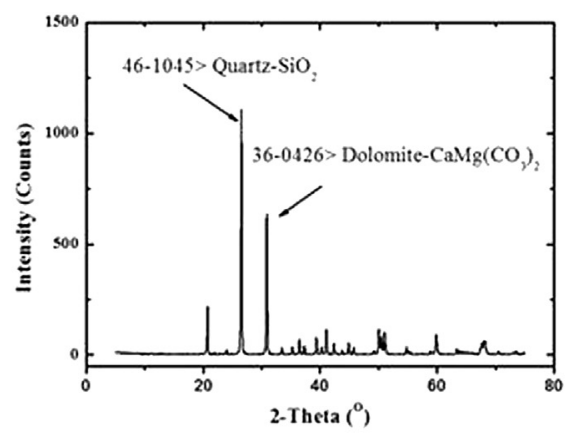

(b)

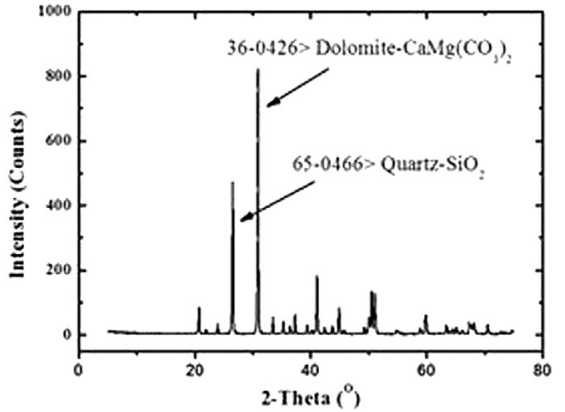

(c)

Fig. 6. XRD results of dolomite specimens at different heat treatment temperatures: (a) unheated; (b) heated at $450{ }^{\circ} \mathrm{C}$; (c) heated at $550{ }^{\circ} \mathrm{C}$.

ductility and zigzag phenomenon in strain vs. stress curve. These characteristics create opportunities for ancient humans to produce more, longer, and thinner flakes. As a result, knapping difficulties are reduced and the productivity is increased substantially. This implies that the prehistoric occupants in SDG employed heat treatment techniques aimed at enhancing knapping performance and efficiency.

\subsection{Identification of heat treated artifacts in SDG}

Color changes, heat damages, and luster are usually considered as the most common and effective criteria for identifying controlled heat treatment (Collins and Fenwick, 1974; Bleed and Maier, 1980; Domański et al., 2009). Zhou et al. (2013)'s experiments suggest that color change could be considered as an effective method of identifying of heat treated stone artifacts at the SDG sites, especially those heated to peak temperatures of $300-400{ }^{\circ} \mathrm{C}$. In fifty seven pieces of experimentally heat-treated blanks, $67 \%(n=38)$ of the pieces turned red. However, no heat damage and luster have been observed. Although the color change seems effective for identifying heat treatment, a few dolomite pebbles with a red color similar to that in heated samples have been found near the SDG sites. In addition, based on the heating experiment of quartzite and quartzite sandstone that we previously conducted (Zhou et al., 2013), no external change has been observed on these rock types. Therefore, we are very cautious about the identification of heat treated artifacts from a limited set of criteria. The 110 pieces (forty five from SDG 2; sixty five from SDG 12) identified heat treated artifacts is a small number compared to the whole assemblage. XRD and SEM have been proved to be accurate methods for their identification. The changes of texture and material composition could be detected and observed. However, due to the high time cost, economic cost, and the destruction of test samples, it is impossible to examine every archaeological lithic artifact with XRD and SEM. We believe there are more heat treated artifacts than we identified.

\subsection{Risk management and heat treatment at SDG}

Risk is usually defined as unpredictable variation in some ecological or economic variable. To prehistoric occupants, risk meant the chance of going without enough resources (Kelly, 1995). Risk of resource failure is a primary influence on hunter-gatherer technology, possibly more so than residential mobility, population size, or the nature of food resources (Torrence, 1989; Collard et al., 2005). Heat treatment technology is useful in risk management especially, responding to high quality raw material resource shortage. Li et al. (2014) discuss behavioral innovations at SDG2 and confirm long distance raw material transportation. Intensive usage of raw material appears necessary in this circumstance. Compression tests have proved heat treatment techniques particularly useful for enhancing knapping performance and efficiency. For responding to raw material resource failure, SDG prehistory inhabitants applied this technique in lithic production. Heat treated lithic artifacts at SDG 2 include cores $(n=2)$, flakes $(n=11)$, debris $(n=9)$, chunks $(n=23)$.

For SDG 12, during its occupation period, which covered the Younger Dryas event, the natural environment in this area fluctuated markedly and usable subsistence resources decreased. Under the harsh environment, the maintainability system should have been built on maintaining effectiveness and minimizing risk. The maintainability system is a strategy designed for an unpredictable schedule and variation in resource availability. The associated tool kit is more variable in order to function in unpredictable situations and in order to be easily repaired and replaced (Bleed, 1986). A mature microblade production system has been identified at SDG12 (Yi et al., 2013). Yi et al. (2014) argue that microblade technology flourished at SDG12 under harsh environments and indicate high residential mobility by the inhabitants. The presence of bone needles and a bone knife handle slotted to accept microblades also implies that microblades were used in manufacturing the sophisticated cold weather clothing required for winter mobility, and also used in manufacturing hunting weaponry (Yi et al., 2014). As we mentioned, heat treatment technology was widely used in the production of microblades, in a counterpart, heat treated microblades and correlated cores have been unearthed at SDG12 (Zhou et al., 2013). This technology improved the efficiency of microblade production and raw material utilization. Correspondingly, the ability to survive and manage risk of the SDG12 inhabitants had been improved greatly. The development of lithic heat treatment technology is thus considered as an important component in the human risk management behavior strategy at SDG.

\subsection{Spread of heat treatment technology}

All the heat treated artifacts of SDG2 from CL4-CL1 date to $32 \mathrm{ka} \mathrm{BP}$ to $20 \mathrm{ka} \mathrm{BP}$. Li et al. (2013b; 2014) report that two broadly different core reduction technologies are identified at SDG2: a large blade technology (CL7 and CL5a, date to $38 \mathrm{ka}$ BP to $34 \mathrm{ka} \mathrm{BP}$ ) and a simple free-hand core reduction and bipolar reduction (CL6, CL5b and CL4-CL1). The number of lithic artifacts unearthed from CL7 and CL5a $(n=25)$ is quiet small compared with the whole assemblage of SDG2 ( $n=11,790)$ (Li et al., 2013a). So, there is also the possibility that heat treated artifacts do exist in this culture layer but not in the area that was excavated. The blade industry is normally thought to be imported from Mongolia and Siberia, and 
the simple flake industry shows a continuous evolution from early Pleistocene to around $20 \mathrm{ka}$ BP in north China. Ornaments and long-distance raw material transportation found in CL4CL1demonstrate the interaction between inhabitants in SDG with other populations (Li et al., 2014). Based on this evidence, we hypothesize that heat treatment technology spread to SDG around 32 ka BP through population interaction. However, we cannot ignore the possibility that this technology spread with a blade technology (including Levallois blades) by population immigration around $38 \mathrm{ka}$ BP. The most likely route by which this technology reached North China is via a northern route which went from Southwest Asia through Central Asia, Siberia and Mongolia to North China, but also continued northeastwards to the Bering Strait (e.g. Dyuktai site, 22-10 ka BP) (Yi and Clarke, 1985), and then to the American continents (Struever, 1973; Greber et al., 1981; Beltrao et al., 1986; Morrow, 1987; Jeske, 1989; Roosevelt et al., 1996). However, more archaeological evidence is needed to confirm this hypothesis.

\subsection{Perspective}

In terms of Paleolithic archaeology, study of this technology can help us to understand early modern human knowledge of raw material selection, cognition, development of lithic knapping techniques, and increasing knowledge of resource exploitation. In turn, this helps in the interpretation of behavioral models and social organization. More than one thousand Paleolithic sties have been found in China, and many contained hearths (Zhou et al., 2012). Suspected heat treated lithic artifacts have been found in some sites, such as late Paleolithic ones in the Nihewan Basin (e.g. Yujiagou site, personal communication). Therefore, heat treatment research has great potential in China and elsewhere in East Asia. Unfortunately, until now, heat treatment of lithic artifacts has been reported only at SDG. There are three reasons for this situation: firstly, heat treatment research has rarely been mentioned in China because most archaeologists were never trained to identify heat treated artifacts during lithic analysis; secondly, a great variety of stone raw materials have been utilized in stone tool production in China, and their external features and mechanical properties vary widely after heat treatment because of the inhomogeneous texture, and this produces obstacles for identification; finally, scientific methods such as rock mechanical tests, XRD, XRF, and SEM have rarely been used in Paleolithic research in China. In view of the importance of heat treatment technology in Palaeolithic research, as well as the current research situation in China, we suggest three research directions: at the starting stage, heat treatment research should be focused on microcrystal silicious rock, as it is easy to identify; secondly, more simulated experiments should be conducted at Late Paleolithic sites, especially those which contain a blade or microblade industry, such as Shizitan and some sites in Nihewan Basin; finally, with the testing results and experimental data accumulation, an identification system of Chinese raw material should be established, as this will promote heat treatment research in China.

\section{Acknowledgments}

The authors would like to deeply thank Professor David Madsen from University of Texas at Austin, US for instructive comments. This work is supported by the Strategic Priority Research Program of the Chinese Academy of Sciences (XDA05130303) and the National Natural Science Foundation of China (11372323), and the project of function development on scientific instruments of Chinese Academy of Sciences.

\section{References}

Aubry, T., Almeida, M., Neves, M.J., Walter, B., 2003. Solutrean Laurel leaf point production and raw material procurement during the Last Glacial Maximum in Southern Europe: two examples from central France and Portugal. In: Soressi, M., Dibble, H.L. (Eds.), Multiple Approaches to the Study of Bifacial Technologies. Museum of Archaeology and Anthropology, University of Pennsylvania, pp. 165-182.

Balme, M.R., Rocchi, V., 2004. Fracture toughness measurements on igneous rocks using a high-pressure, high-temperature rock fracture mechanics cell. Journal of Volcanology and Geothermal Research 132, 159-172.

Beltrao, M.C., Enriquez, C.R., Danon, J., Zuleta, E., Poupeau, G., 1986. Thermoluminescence dating of burnt cherts from the Alice Boer Site (Brazil). In: Bryan, A.L. (Ed.), New Evidence for the Pleistocene Peopling of the Americas, Center for the Study of Early Man. University of Maine, pp. 203-213.

Bleed, P., 1986. The optimal design of hunting weapons: maintainability or reliability. American Antiquity 51, 737-747.

Bleed, P., Maier, M., 1980. An objective test of the effects of heat treatment of flakeable stone. American Antiquity 45, 502-507.

Bradley, B., Anikovich, M., Giria, E., 1995. Early Upper Palaeolithic in the Russian Plain: streletskayan flaked stone artefacts and technology. Antiquity 69, 989-998.

Brown, K.S., Marean, C.W., Herries, A.I.R., Jacobs, Z., Tribolo, C., Braun, D., Roberts, D.L., Meyer, M.C., Bernatchez, J., 2009. Fire as an engineering tool of early modern humans. Science 325, 859-862.

Chen, C., Wang, X.Q., 1989. Upper Paleolithic microblade industries in North China and their relationships with North-East Asia and North America. Arctic Anthropology 26, 127-156.

Clark, J.D., Harris, J.W.K., 1985. Fire and its roles in early hominid lifeways. African Archaeological Review 3, 3-27.

Clark, J.D., Williams, M.A., 1986. Paleoenvironments and prehistory in North Central India: a preliminary report. In: Jacobson, J. (Ed.), Studies in Archaeology of India and Pakistan. American Institute of Indian Studies, New Delhi, pp. 19-41.

Clemente, I., 1995. Silex y lustre termico en el paleolitico medio: alteration o tecnico de talla? El ejemplo de mediona I (Alt Penedes, Barcelona). I Congreso de Arqueologia Peninsular, Porto 1993. Trabalhos de Antropologia e Etnologia 35 (3), 37-45.

Collard, M., Kemery, M., Banks, S., 2005. Causes of toolkit variation among huntergatherers: a test of four competing hypotheses. Canadian Journal of Archaeology 29, 1-19.

Collins, M.B., Fenwick, J.M., 1974. Heat treating of chert: methods of interpretation and their application. Plains Anthropology 19, 134-145.

Copeland, L., 1998. The Middle Paleolithic flint industry of Ras el-Kelb. In: Copeland, L., Moloney, N. (Eds.), The Mousterian Site of Ras el-Kelb, Lebanon, British Archaeological Reports (International Series), pp. 73-101. Oxford.

Dolukhanov, P. Shukurov, A., 2004. Colonisation of Northern Eurasia by early modern humans as viewed through the evidence of radiocarbon dating. In: Highham, T., Ramsay, C.B., Owen, C. (Eds.), Radiocarbon and Archaeology. Proceedings of the Fourth International Symposium. School of Archaeology, Oxford University, pp. 9-14.

Domanski, M., Webb, J., 1992. Effect of heat treatment on siliceous rocks used in prehistoric lithic technology. Journal of Archaeological Science 19, 601-614.

Domanski, M., Webb, J., 2007. A review of heat treatment research. Lithic Technology 32, 153-194.

Domański, M., Webb, J., Glaisher, R., Gurba, J., Libera, J., Zakoscielna, A., 2009. Heat treatment of Polish flints. Journal of Archaeological Science 36, 1400-1408.

Duttine, M.P., 2005. Effects of thermal treatment on TL and EPR of flints and their importance in TL-Dating: application to French Mousterian sites of Les Forets (Dordogne) and Jiboui (Drome). Radiation Measurements 39, 375-385.

Edwards, P.C., Edwards, W.I., 1990. Heat treatment of chert in the Natufian period. Mediterranean Archaeology 3, 1-5.

Gao, X., Yuan, B.Y., Pei, S.W., Wang, H.M., Chen, F.Y., Feng, X.W., 2008. Analysis of sedimentary-geomorphologic variation and the living environment of hominids at the Shuidonggou Paleolithic site. Chinese Science Bulletin 53, 2025-2032.

Gao, X., Wang, H.M., Pei, S.W., Chen, F.Y., et al., 2013. Shuidonggou Excavation and Research (2003-2007) Report. Science Press, Beijing, China.

Gao, X., Wang, H.M., Liu, D.C., Pei, S.W., Chen, F.Y., Zhang, X.L., Zhang, Y., 2009. A study of fire-use activities at Shuidonggou locality 12 (in Chinese). Acta Anthropologica Sinica 28 (4), 329-336.

Gao, X., Zhang, X.L., Yang, D.Y., Shen, C., Wu, X.Z., 2010. Revisiting the origin of modern humans in China and its implications for global human evolution. Science China Series D-Earth Sciences 40, 1287-1300.

Greber, N., Davis, R.S., DuFresne, A.S., 1981. The microcomponent of the Ohio Hopewell lithic technology. Annals of the New York Academy of Sciences 376, 489-528.

Griffiths, D.R., Bergman, C.A., Clayton, C.J., Ohnuma, K., Robins, G.V., Seeley, N.J., 1987. Experimental investigation of the heat treatment of flint. In: Sieveking, G., Newcomer, M.H. (Eds.), The Human Uses of Flint and Chert. Cambridge University Press, Cambridge, pp. 263-267.

Guan, Y., Gao, X., Wang, H.M., Chen, F.Y., Pei, S.W., Zhang, X.L., Zhou, Z.Y., 2011. Spatial analysis of intra-site use at a Late Paleolithic site at Shuidonggou, Northwest China. Chinese Science Bulletin 56, 3457-3463.

Guibert, P., Perraut, A., Duttine, M., Lahaye, C., Brenet, M., Folgado, M., 2004. Datation par thermoluminescence $(\mathrm{TL})$ couplée à la résonance paramagnétique 
électronique (RPE) de silex chauffés provenant du site moustérien des Forest (Saint-Martin-de-Gurcon, Dordogne, France). Paleo 16, 117-128.

Heuze, F.E., 1983. High-temperature mechanical, physical and thermal properties of granitic rocks - a review. International Journal of Rock Mechanics and Mining Sciences \& Geomechanics Abstracts 20, 3-10.

Inizan, M.I., Lechevallier, M., Plumet, P., 1992. A technological marker of the penetration into North America: pressure microblade debitage, its origin in the Paleolithic of North Asia and its diffusion. Materials Research Society Symposium Proceedings 267, 661-681.

Jeske, R., 1989. Economies in raw material use by Pre-historic hunter-gatherers. In: Torrence, R. (Ed.), Time, Energy and Stone Tools. Cambridge University Press, Cambridge, pp. 34-45.

Kelly, R.L., 1995. The Foraging Spectrum: Diversity in Hunter-Gatherer Lifeways. Smithsonian Institution Press, Washington, DC.

Lau, J.S.O., Gorski, B., Jackson, R., 1995. The effects of temperature and water saturation on mechanical properties of Lac du Bonnet pink. In: The 8th International Congress on Rock Mechanics, Tokyo, pp. 1167-1172.

Li, F., Gao, X., Chen, F.Y., Pei, S.W., Zhang, Y., Zhang, X.L., Liu, D.C., Zhang, S.Q., Guan, Y., Wang, H.M., Kuhn, S.L., 2013a. The development of Upper Palaeolithic China: new results from the Shuidonggou site. Antiquity 87 (336), 368-383.

Li, F., Kuhn, S.L., Gao, X., Chen, F.Y., 2013b. Re-examination of the date of large blade technology in China: a comparison of Shuidonggou Localities 1 and 2. Journal of Human Evolution 64, 161-168.

Li, F., Chen, F.Y., Gao, X., 2014. "Modern behaviors" of ancient populations at Shuidonggou Locality 2 and their implications. Quaternary International 347, 66-73. http://dx.doi.org/10.1016/j.quaint.2014.04.001.

Liao, H., 1989. Geological characteristics of Ningxia Hui autonomous region (in Chinese). Chinese Regional Geology, 314-323.

Liu, D., Wang, X., Gao, X., Xia, Z.K., Pei, S.W., Chen, F.Y., Wang, H.M., 2009. Progress in the stratigraphy and geochronology of the Shuidonggou site, Ningxia, North China. Chinese Science Bulletin 54, 3880-3886.

Madsen, D.B., Li, J., Brantingham, P.J., Gao, X., Robert, E.G., Bettinger, R., 2001. Dating Shuidonggou and the Upper Paleolithic blade industry in North China. Antiquity 75, 706-716.

Morrow, C.A., 1987. Blades and Cobden chert: a technological argument for their role as markers of regional identification during the Hopewell Period in Illinois. In: Johnson, J.K., Morrow, C.A. (Eds.), The Organization of Core Technology. Westview Press, Colorado, pp. 119-149.

Owen, L.R., 1988. Blade and Microblade Technology: Selected Assemblages from the North American Arctic and the Upper Palaeolithic of Southwest Germany
(PhD dissertation). In: British Archaeological Reports International Series 441 Oxford.

Roosevelt, A.C., Lima da Costa, M., Lopes Machado, C., Michab, M., Mercier, N., Valladas, H., Feathers, J., Barnett, W., Imazio da Silveira, M., Henderson, A. Silva, J., Chernoff, B., Reese, D.S., Holman, J.A., Toth, N., Schick, K., 1996. Paleoindian cave dwellers in the Amazon: the peopling of the Americas. Science 272 373-384.

Sanlaville, P., 1998. The Deposits of Ras el-Kelb in the frame-work of the regional chronostratigraphy. In: Copeland, L., Moloney, N. (Eds.), The Mousterian Site of Ras el- Kelb, Lebanon. British Archaeological Reports International Series, vol. 706, pp. 37-44. Oxford.

Struever, S., 1973. Chert utilization in Lower Illinois valley prehistory. In: Lathrap, D.W., Douglas, J. (Eds.), Variation in Anthropology: Essays in Honor of John Mc Gregor. Illinois Archaeological Survey, Urbana, pp. 61-73.

Torrence, R., 1989. Re-tooling: towards a behavioral theory of stone tools. In: Torrence, R. (Ed.), Time, Energy and Stone Tools. Cambridge University Press, Cambridge.

Turcotte, D.L., Newman, W.I., Shcherbakov, R., 2003. Micro and macroscopic models of rock fracture. Geophysical Journal International 152, 718-728.

Yi, MJ., Barton, L., Morgan, C., Liu, D.C., Chen, F.Y., Zhang, Y., Pei, S.W., Guan, Y., Wang, H.M., Gao, X., Bettinger, R.L., 2013. Microblade technology and the rise of serial specialists in north-central China. Journal of Anthropological Archaeology 32 (2), 212-223.

Yi, M.J., Bettinger, R.L., Chen, F.Y., Pei, S.W., Gao, X., 2014. The significance of Shuidonggou Locality 12 to studies of hunter-gatherer adaptive strategies in North China during the Late Pleistocene. Quaternary International 347, 97-104. http:/ dx.doi.org/10.1016/j.quaint.2014.04.009.

Yi, S., Clarke, G., 1985. The "Dyuktai Culture" and new world origins. Current Anthropology 26, 1-20.

Zhang, L.Y., Mao, X.B., Lu, A.H., 2009. Experimental study on the mechanical properties of rocks at high temperature. Science China Series E-Technological Sciences 52, 641-646.

Zheng, Z., Li, Y., 1991. The new advances in the study of the Ordovidian system in Helanshan Area (in Chinese). Geoscience 5, 119-137.

Zhou, Z.Y., Guan, Y., Wang, C.X., Gao, X., 2012. Remains of human fire-use: an overview of paleolithic hearth and human fire-use behavior. Acta Anthropologica Sinica 31 (1), 24-40.

Zhou, Z.Y., Guan, Y., Gao, X., Wang, C.X., 2013. Heat treatment and associated early modern human behaviors in the Late Paleolithic at the Shuidonggou Site. Chinese Science Bulletin 58, 1801-1810. 